\title{
Molecular Mechanisms Associated with Chromosomal and Microsatellite Instability in Sporadic Glioblastoma multiforme
}

\author{
Ramon Martinez ${ }^{a}$ Hans-K. Schackert $^{\mathrm{b}}$ Jens Plaschke ${ }^{\mathrm{b}} \quad$ Gustavo Baretton $^{\mathrm{c}}$ \\ Hella Appelt ${ }^{b}$ Gabriele Schackert ${ }^{a}$ \\ Departments of a Neurosurgery and bSurgical Research and c Institute of Pathology of the University of Dresden, \\ Dresden, Germany
}

\author{
Key Words \\ Glioblastoma multiforme - Tumorigenesis - Mismatch \\ repair $\cdot$ Chromosomal instability
}

\begin{abstract}
Objective: Two chromosomal instability (CIN) pathways are described in glioblastoma multiforme (GBM), type 1 and type 2, which can be observed in up to $70 \%$ of the cases. Microsatellite instability (MSI) plays a pathogenic role in sporadic cancers such as colon, gastric and endometrial carcinomas with deficient mismatch repair (MMR). We aimed to perform a comprehensive analysis of the relationship between $\mathrm{CIN}$ and MSI mechanisms in sporadic glioblastomas. Methods: 129 GBMs were examined (109 newly diagnosed and 20 relapses) investigating $\mathrm{MSI}$, immunohistochemical expression of MMR proteins as well as sequencing and promoter methylation of $h M L H 1$. We characterized the molecular changes frequently correlated with $\mathrm{CIN}$ in $\mathrm{MSI}+\mathrm{GBMs}$ and compared them with 26 microsatellite-stable tumors. $R \boldsymbol{R}$ sults: Low-level MSI was observed in 11 of 129 (8.5\%) cases and was higher in relapses than in primary GBMs (25 vs. 5.5\%, $p=0.027$ ). High-level MSI was not found in any case. A deficient expression of MLH1 and PMS2 without $h M L H 1$ inactivation was observed only in one giant cell GBM. $55 \%$ of the MSI+ GBMs showed a profile
\end{abstract}

which did not correspond to one of the known CIN pathways. An inverse association was observed between MSI and mutations of both p53 and PTEN. Conclusions: Our data suggest that $\mathrm{CIN}$ and MSI contribute to the genomic instability in GBMs via independent pathways. Since MSI was significantly more frequent in relapses, it might play a role in the malignant progression of GBM.

Copyright $\odot 2004$ S. Karger AG, Basel

\section{Introduction}

Genomic instability plays a key role in the pathogenesis of numerous solid tumors [1, 2]. One form is chromosomal instability (CIN), characterized by multiple gains and losses in specific chromosome regions [1]. In glioblastoma multiforme (GBM), the most frequent primary brain tumor in adults [3, 4], CIN was observed to be connected with two pathways, typically harboring either mutations of $p 53$ or amplification of the epidermal growth factor receptor $(E G F R)$ oncogene. This condition was termed type 1 and type 2 GBM, respectively [5-9]. However, about $30 \%$ of GBMs show molecular alterations that correspond neither to type 1 nor to type 2 pathways $[5,10$, $11]$.

\begin{tabular}{ll}
\hline KARGER & ( ) 2004 S. Karger AG, Basel \\
0030-2414/04/0665-0395\$21.00/0 \\
$\begin{array}{l}\text { Fax +4161306 12 34 } \\
\begin{array}{l}\text { E-Mail karger@karger.ch } \\
\text { www.karger.com }\end{array}\end{array}$ & $\begin{array}{l}\text { Accessible online at: } \\
\text { www.karger.com/ocl }\end{array}$
\end{tabular}

R. Martinez, MD, Department of Neurosurgery, Klinikum Fulda

Academic Hospital, University of Marburg

Pacelliallee 4, DE-36043 Fulda (Germany)

Tel. +49 661845801 , Fax +49 $6612506807 /+49661845802$

E-Mail voelter.martinez@t-online.de 
A second form of genomic instability, microsatellite instability (MSI), typically displays length mutations in microsatellite sequences in noncoding and in coding regions of genes such as PTEN, TGF $\beta R$-II, IGFIIR, BAX and $E 2 F 4$ [12-15]. MSI was suggested to be the consequence of the inactivation of mismatch repair (MMR) genes $[12,13,16]$ and was observed in hereditary syndromes, i.e. hereditary nonpolyposis colorectal cancer (HNPCC) with a frequency of up to $90 \%[13,16]$, and sporadic malignancies such as colorectal (15\%) [17], endometrial (15\%) [18], non-small-cell lung (35\%) [19], head and neck (28\%) [20], gastric (10\%) [21] or prostate cancers $(8.5 \%)$ [22]. In sporadic tumors, MSI was found to be most frequently caused by $h M L H 1$ promoter hypermethylation [23]. The relevance of MSI in sporadic cancers is confirmed by molecular and clinicopathological observations such as an inverse relationship between MSI and $p 53$ mutations in gastric cancer [19] and colorectal cancer cell lines [24], the association of MSI with the malignant progression in gastric tumors [25] and metastatic gastric cancers [26] or the distinct histopathological features of MSI+ colorectal cancer compared to their MSS (microsatellite-stable) homologues [27].

A comprehensive analysis of the molecular basis of MSI and the relationship with the CIN-mediated pathways has not been performed in glioblastoma. MSI was described in GBM in some previous studies but either small tumor series are available or only few polymorphic repeats were used. Therefore, we investigated 129 sporadic GBMs for MSI using 15 polymorphic repeats and performed immunohistochemistry for the MMR proteins hMLH1, hPMS2, hMSH2 and hMSH6, mutational analysis of $h M L H 1$ as well as evaluation of $h M L H 1$ promoter methylation. To elucidate the (in)dependence of MSI and the CIN, we carried out loss of heterozygosity (LOH) studies at loci involved in GBM pathogenesis, mutational screening of $p 53$ and PTEN and investigated EGFR amplification in both MSI and MSS tumors.

\section{Material and Methods}

\section{GBM Samples}

129 paired samples of blood and tumor tissue were obtained from GBM patients treated at the Department of Neurosurgery of the University of Dresden. Portions of the fresh tumor samples were frozen in liquid nitrogen and stored at $-80^{\circ} \mathrm{C}$. Tumor tissue was evaluated at the Institute of Pathology, University of Dresden, Germany, according to the World Health Organization (WHO) criteria [3]. Formalin-fixed, paraffin-embedded specimens were used for immunohistochemistry. Leukocyte and tumor DNA were isolated applying the QIAamp ${ }^{\circledR}$ DNA Mini Kit (Qiagen, Hilden, Germany). This study was conducted with the consent of the institutional ethics committee and an informed consent from each patient or his/her caretaker was obtained.

\section{MSI Analysis}

Matched genomic tumor and blood DNA were amplified by PCR using 15 primer pairs $[28,29]$ : mononucleotides (BAT25, BAT26, BAT40, TGß-RIIpA, GTBPIn5, GTBPIn9), dinucleotides (D5S346, D17S250, D10S197, D2S123, D18S58, D13S153, D3S1300, D3S1619) and a tetranucleotide (MYCL1). PCR was performed using 50-100 ng of template DNA. Amplified PCR products were electrophoresed on a $6.5 \%$ Long Ranger polyacrylamide gel on an Automated Laser Fluorescence (ALF express ${ }^{\circledR}$ ) sequencing device (Amersham Pharmacia Biotech, Freiburg, Germany) and analyzed using the ALLELELINKS ${ }^{\circledR} 1.00$ software (Amersham Pharmacia Biotech). MSI was defined by the presence of novel alleles in tumor DNA that were absent in corresponding leukocyte DNA [30] and confirmed in two independent analyses. Informative dinucleotide repeats without MSI were assessed for $\mathrm{LOH}$ as described [31, 32]. Three categories were defined according to the MSI findings: highlevel MSI (MSI-H, $\geq 40 \%$ of studied loci altered), low-level MSI (MSI-L, <40\%) and MSS (no analyzed marker unstable) [27, 28, 33].

\section{Immunohistochemistry of MMR Proteins}

Immunostaining for hMLH1 (clone G168-15, PharMingen Int., San Diego, Calif., USA), hMSH2 (clone FE11, Oncogene Res. Products, Cambridge, Mass., USA), hMSH6 (clone 44, Transduction Lab., Lexington, UK) and hPMS2 (A16-4, PharMingen Int., San Diego, Calif., USA) was performed in all MSI+ tumors as described [34]. Tumor cells exhibiting no or reduced nuclear staining were considered as having an abnormal pattern. The relative densitometry of MMR protein expression (compared to the negative controls) was performed using the Meta-Vue ${ }^{\circledR}$ software (Universal Imaging Systems, Downingtown, Pa., USA).

\section{Mutational Analysis of $\mathrm{hMLH} 1, \mathrm{p} 53$ and PTEN}

We sequenced all coding exons and exon-intron boundaries of $h M L H 1, p 53$ and PTEN from leukocyte and tumor DNA. After PCR amplification, the products were electrophoresed in $0.8 \%$ agarose gel and subjected to cycle sequencing reactions using the Thermo Sequenase ${ }^{\circledR}$ Fluorescent Cycle Sequencing kit (Amersham Pharmacia Biotech). After denaturation, the cycle-sequencing products were resolved using a denaturing $6.5 \%$ Long Ranger polyacrylamide gel on a sequencing device. Primer sequences and amplification conditions were described elsewhere and are available from the authors [3537].

\section{Methylation Status of the hMLH1 Promoter Region}

Leukocyte and tumor DNA were digested with methylation-sensitive or insensitive restriction endonucleases, HpaII (Life Technologies, Karlsruhe, Germany) or MspI (New England Biolabs, Frankfurt am Main, Germany), respectively. After digestion of $250 \mathrm{ng}$ of genomic DNA, $25 \mathrm{ng}$ from each digest was used as the template for PCR amplification of an 829-bp fragment which contains the promoter region, the exon 1 and a part of the intron 1 of the $h M L H 1$ and harbors five $H p a I I$ sites. The amplification products were visualized using a $1 \%$ agarose gel. Primer sequences and PCR conditions were described previously [23]. The breast cancer cell line CAL51 was used as positive control [38]. 
Table 1. Clinicopathological data and relationship with MSI findings of the 129 analyzed sporadic GBMs

\begin{tabular}{|c|c|c|c|c|c|}
\hline Age range & Male/female & $\begin{array}{l}\text { Previous } \\
\text { astrocytoma }\end{array}$ & $\begin{array}{l}\text { Family or patient } \\
\text { tumor history }\end{array}$ & $\begin{array}{l}\text { Long-term survival } \\
\text { patients, months }\end{array}$ & MSI-L \\
\hline$<18$ years $(\mathrm{n}=1)$ & $1 / 0$ & 0 & none & 0 & 0 \\
\hline $18-55$ years $(\mathrm{n}=52)$ & $32 / 20$ & $\begin{array}{l}8 \mathrm{~A}-\mathrm{II} \\
3 \mathrm{~A}-\mathrm{II}\end{array}$ & 1 pinealoma & $\begin{array}{l}\text { 5/52 }(9.6 \%) \\
\text { (mean: 55; range: } 37-70)\end{array}$ & $3 / 52(5.8 \%)$ \\
\hline$>55$ years $(n=76)$ & $48 / 28$ & $\begin{array}{l}3 \mathrm{~A}-\mathrm{I} \\
2 \mathrm{~A}-\mathrm{II}\end{array}$ & $\begin{array}{l}3 \mathrm{CRC} \\
1 \text { breast cancer } \\
1 \mathrm{NF}-2\end{array}$ & $\begin{array}{l}\text { 2/76 }(2.6 \%) \\
\text { (mean: 59; range: } 48-70)\end{array}$ & $8 / 76(10.5 \%)$ \\
\hline
\end{tabular}

A-I = Astrocytoma WHO grade I; A-II = astrocytoma WHO grade II; A-III = astrocytoma WHO grade III; CRC = colorectal cancer; $\mathrm{NF}-2$ = neurofibromatosis type 2 .

\section{LOH Analysis and Semiquantitative PCR Analysis of EGFR}

Amplification

LOH at 10q23-24 was studied with the markers D10S215 and D10S541 (flanking PTEN), PTENCA (PTEN intragenic marker), D10S583 and D10S579 (telomeric and centromeric to PTEN, respectively). Analysis of LOH at $17 \mathrm{p} 13$ (p53) was done with the TP53 and a $p 53$ intragenic marker. Allelic losses at $9 \mathrm{p} 21$ (p16/CDKN2A, $p 14^{A R F}$ and $\left.p 15 / C D K N 2 B\right)$ and $13 \mathrm{q} 14$ (RB1) were studied with the primers D9S1748, D9S171, D9S1749, D13S153 and D13S267, respectively. $\mathrm{LOH}$ at $1 \mathrm{p} 35-36$ and $19 \mathrm{q} 13$ was assessed with the markers D1S468, D1S482, D19S112 and D19S412 [39, 40]. Primer sequences and PCR amplification conditions are based on Genome Database entries (www.gdb.org). To detect EGFR amplification a differential PCR with the cystic fibrosis transmembrane regulator (CFTR) gene was carried out, as previously described [40].

\section{Statistical Analysis}

Contingency analyses between variables were performed using a two-tailed Fisher's exact test and a t test. The relationship between MSI and other variables was evaluated by multiple regression analysis. Odds ratios (ORs) and 95\% confidence intervals (CIs) were obtained through logistic regression. A value of $p<0.05$ was considered to be statistically significant.

\section{Results}

109 newly diagnosed GBMs and 20 relapses were analyzed. Sixteen of the 109 newly diagnosed GBM patients suffered from a previous lower grade astrocytoma (WHO grades II and/or III). A further 7 patients had a survival time of more than 36 months after surgery (long-term survivors). Only 4 patients had a personal history of cancer ( 3 colorectal carcinoma and 1 breast cancer). There was no family history of cancer in any of the cases. Detailed clinical data of the patients are presented in table 1 .

\section{MSI Status}

The total MSI rate was 8.5\% (11/129 patients). Lowlevel MSI was evidenced in 6 of 109 newly diagnosed GBMs $(5.5 \%)$ and in 5 of the 20 relapses $(25 \%)$ (fig. 1). MSI-H was not observed. Fourteen of the 1,007 evaluable dinucleotides (1.4\%) and 2 out of 120 evaluable tetranucleotides $(1.7 \%)$ were unstable. None of the $11 \mathrm{MSI}+$ tumors showed instability of the mononucleotide repeats. The most sensitive markers were D5S346 (4/16 unstable markers), D13S153 (3/16 unstable repeats) and D3S1619 (2/16 instability cases). A statistically significant association between MSI and any of the analyzed markers was not found.

The MSI rate in patients older than 55 years was $9.5 \%$ (this cut-off level showed the lowest $\mathrm{p}$ value), and $4.4 \%$ in patients younger than 55 years $(p=0.26)$. There were no significant associations between gender and the MSI status $(\mathrm{p}=0.21)$.

The presence of MSI in relapsed GBMs was significantly higher $(\mathrm{p}=0.0274,95 \% \mathrm{CI}$ ) than in newly diagnosed tumors. MSI was more frequently detected in glioblastoma patients with a previous low-grade astrocytoma than in those with clinically de novo glioblastomas $(12.5$ vs. $6.5 \%, \mathrm{p}=0.15)$.

\section{Immunohistochemical Studies}

Ten of $11 \mathrm{MSI}+\mathrm{GBMs}$ stained positive for all MMR proteins. Complete loss of hPMS2 and reduced expression of hMLH1 were found in a giant-cell GBM (fig. 2), although only the giant cells were affected. The non-giant tumor cells stained positive for all MMR proteins. Densitometric analyses of hMLH1 expression was performed in 50 giant tumor cells and compared with hMLH1 expression in 50 non-giant tumor cells and 50 cells of the nega- 
Fig. 1. Upper row: microsatellite instability at markers D3S1619 (case G6) and D10S197 (case G1). N and T mean constitutional and tumor DNA, respectively. Arrow indicates novel peaks observed in tumor DNA. Lower row left: loss of heterozygosity at marker D13S153 (case G11). N and T mean constitutional DNA and tumor DNA. Arrow indicates allelic loss. Lower row right: analysis of $h M L H 1$ promoter methylation of the giantcell GBM (case G5). The HpaII- and MspIdigested DNA ( $\mathrm{H}$ and $\mathrm{M}$, respectively) showed no amplification of the promoter fragment (829 bp) of $h M L H 1$, indicating no methylation of the 5 cytosine residues within the $\mathrm{CpG}$ islands of the 5 restriction sites within the fragment. Leukocyte DNA (B5) from the patient was also analyzed. As negative control (NC) we used leukocyte DNA from a healthy Caucasian adult. The breast cancer cell line CAL51, which was previously observed to harbor $h M L H 1$ promoter hypermethylation, was used as positive control. $\mathrm{U}$ and $\mathrm{W}$ stand for undigested DNA and water, respectively.

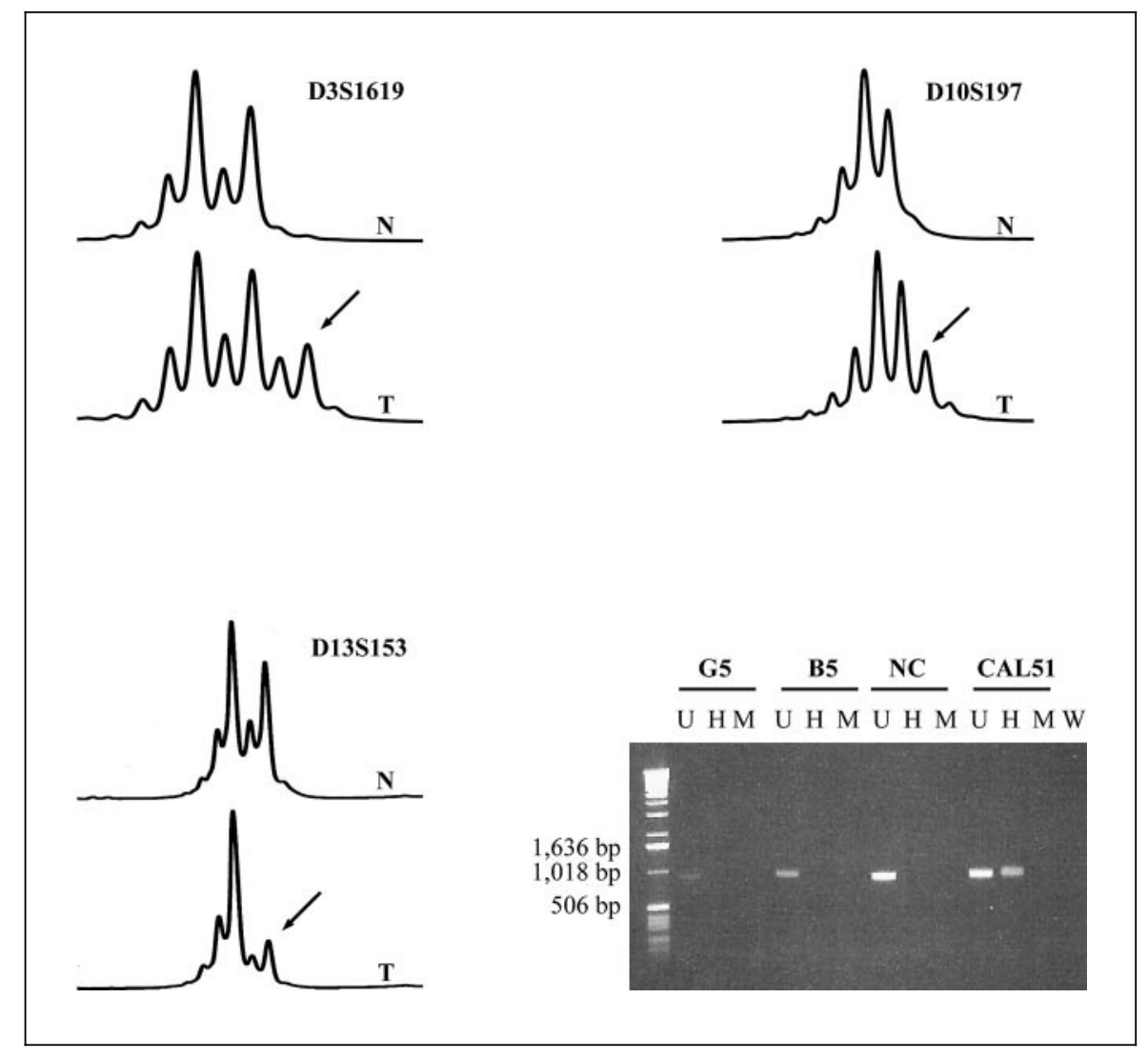

Table 2. Comparative analysis of CIN-mediated pathways in MSI+ and MSS glioblastomas

\begin{tabular}{lllllllll}
\hline & $\begin{array}{l}\text { LOH } \\
p 53\end{array}$ & $\begin{array}{l}\text { Mut. } \\
p 53\end{array}$ & $\begin{array}{l}\text { EGFR } \\
\text { amplification }\end{array}$ & $\begin{array}{l}\text { LOH } \\
\text { PTEN }\end{array}$ & $\begin{array}{l}\text { Mut. } \\
\text { PTEN }\end{array}$ & Type 1 GBM & $\begin{array}{l}\text { Type 2 GBM } \\
\text { Non-type 1, } \\
\text { non-type 2 GBM }\end{array}$ \\
\hline MSI+ GBM & $3 / 11(27.3 \%)$ & $1 / 11(9.1 \%)$ & $4 / 11(36.4 \%)$ & $8 / 11(72.7 \%)$ & $2 / 11(18.2 \%)$ & $1 / 11(9.1 \%)$ & $4 / 11(36.4 \%)$ & $6 / 11(54.5 \%)$ \\
MSS GBM & $4 / 26(15.4 \%)$ & $7 / 26(26.9 \%)$ & $12 / 26(46.2 \%)$ & $21 / 26(80.8 \%)$ & $12 / 26(46.2 \%)$ & $7 / 26(26.9 \%)$ & $12 / 26(46.2 \%)$ & $7 / 26(26.9 \%)$
\end{tabular}

Mut. = Mutation.

tive control. There was a statistically significant difference of hMLH1 expression between giant cells and nongiant cells ( $t$ test: $p=0.0005$ ).

\section{Analysis of the Sequence and Promoter Methylation of hMLH1}

By sequencing the 19 coding exons and flanking intron boundaries of the $h M L H 1$ in the giant cell GBM with reduced hMLH1 expression, neither germline nor somatic genetic alterations were detected. No $h M L H 1$ promoter fragment appeared from either tumor DNA or constitutional DNA after HpaII digestion, ruling out a hyper- methylation of the 5 tested cytosine residues in the promoter region of $h M L H 1$ (fig. 1).

\section{Analysis of the CIN-Mediated Pathways}

We examined tumor and leukocyte DNA from 37 patients, $11 \mathrm{MSI}+$ and $26 \mathrm{MSS}$ GBMs as controls. In MSI+ glioblastomas, the sequence analysis of $p 53$ evidenced alterations only in one tumor, a giant cell GBM $(1 / 11,9 \%)$. Two single base pair exchanges were observed on exon 5 in codon 175 (CGC $\rightarrow$ CAC) and exon 6 in codon 199 (GGA $\rightarrow$ AGA), predicting the substitution of histidine for arginine and arginine for glycine, respective- 


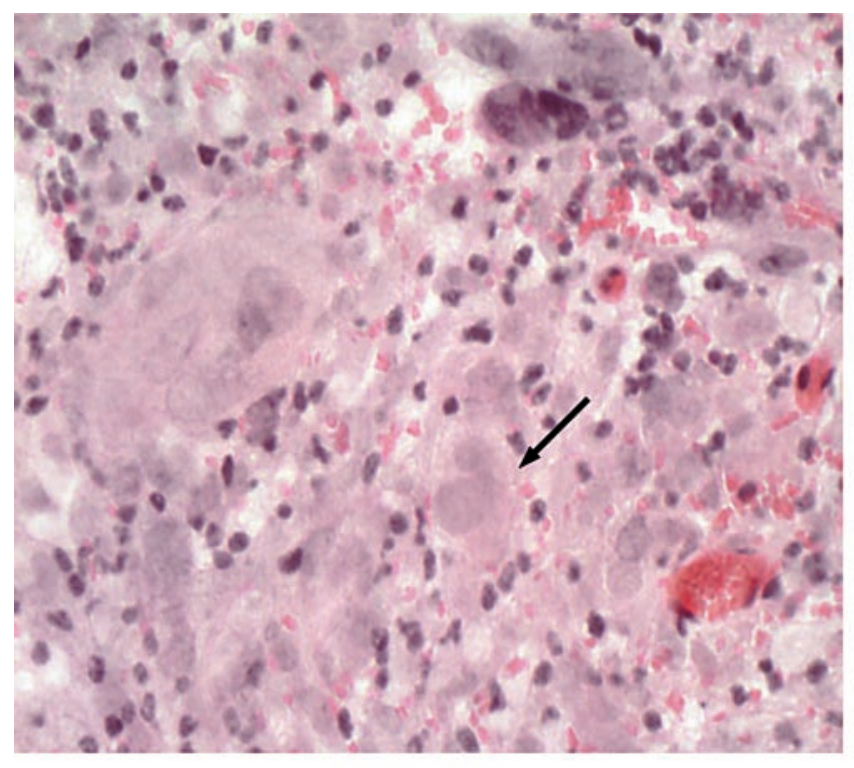

hMLH1

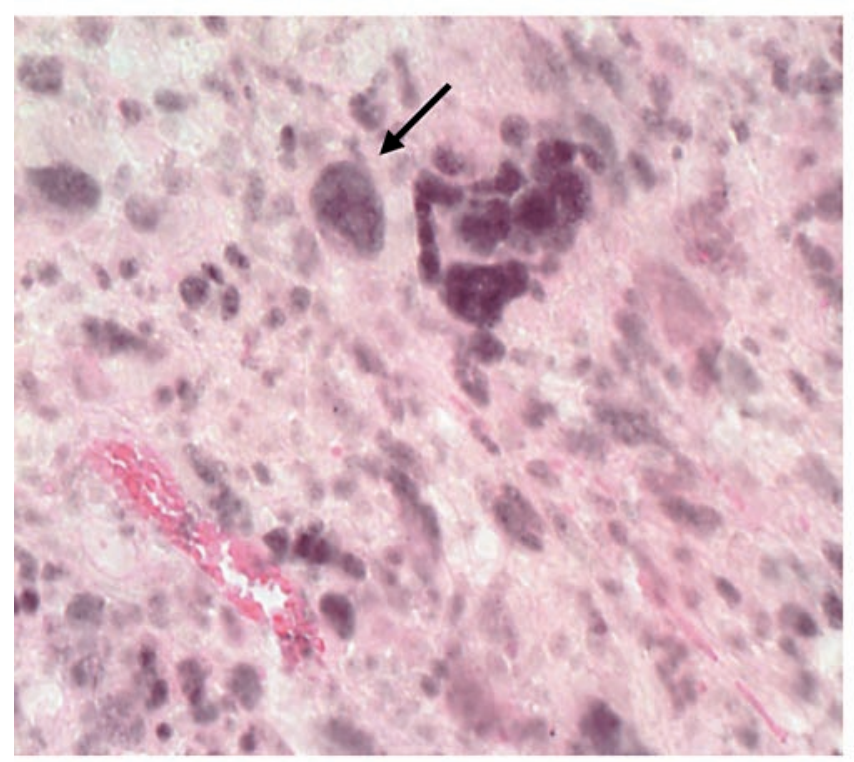

hMSH2

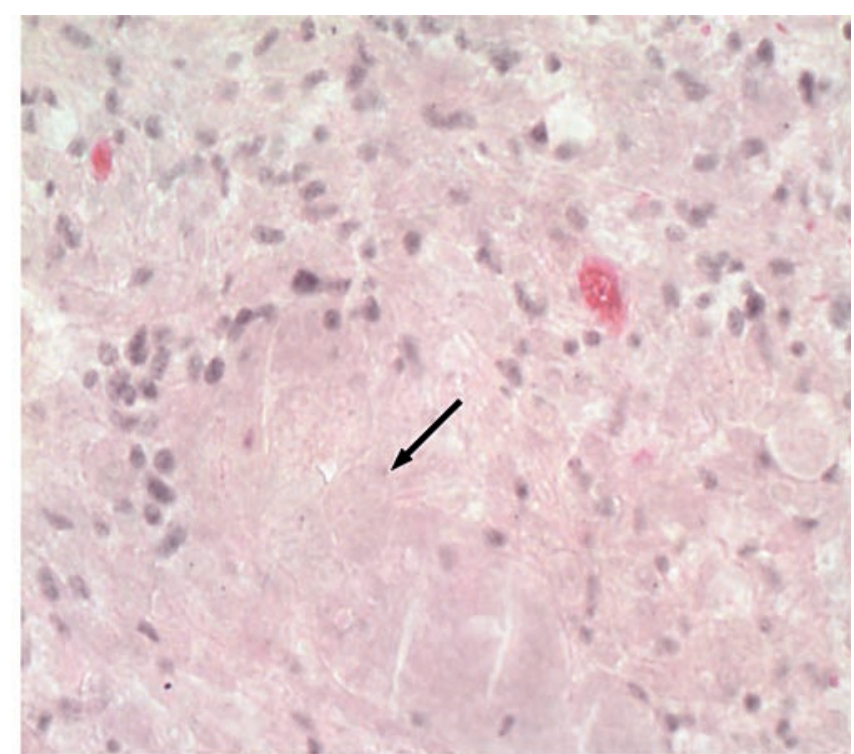

hPMS2

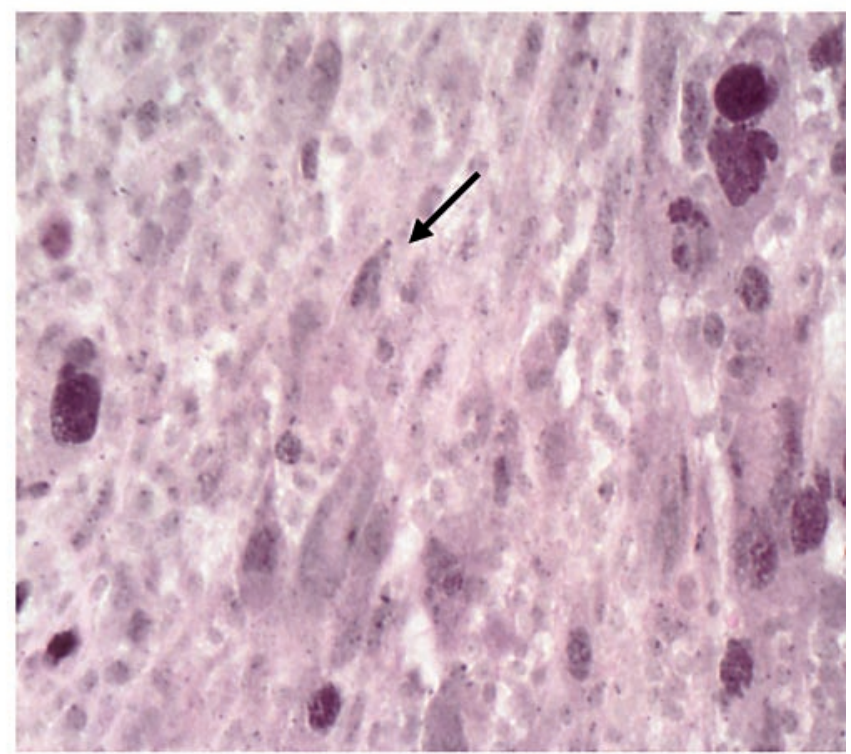

hMSH6

Fig. 2. Immunohistochemical studies of hMLH1 $(\times 200)$, hPMS2 $(\times 200)$, hMSH2 $(\times 400)$ and hMSH6 $(\times 400)$ of the giant-cell GBM (case G5). Arrows show a reduced expression of hMLH1 and a loss of expression of hPMS2 in the giant tumor cells (upper row). The non-giant tumor cells show a positive expression of both gene products. Positive nuclear patterns of hMSH2 and hMSH6 are observed in both giant and non-giant glioblastoma cells (indicated by the arrow). 
Table 3. Molecular findings in MSI+ glioblastomas

\begin{tabular}{|c|c|c|c|c|c|c|c|c|}
\hline Case & $\begin{array}{l}\text { Primary/ } \\
\text { relapse }\end{array}$ & MSI & $\begin{array}{l}\text { Aberrant } \\
\text { MMR protein }\end{array}$ & $E G F R / C F T R$ & $p 53$ & PTEN & $p 15 / p 16$ & $R B 1$ \\
\hline G1 & Primary & $\begin{array}{l}\text { D13S153 } \\
\text { D10S197 }\end{array}$ & No & 1.5 & $\begin{array}{l}\text { Het } \\
\text { No mutation }\end{array}$ & $\begin{array}{l}\text { Het } \\
\text { No mutation }\end{array}$ & $\mathrm{LOH}$ & $\mathrm{LOH}$ \\
\hline G2 & Primary & MYCL1 & No & 1.2 & $\begin{array}{l}\text { Het } \\
\text { No mutation }\end{array}$ & $\begin{array}{l}\text { Het } \\
\text { No mutation }\end{array}$ & Het & n.i. \\
\hline G3 & Primary & D18S58 & No & 18.4 & $\begin{array}{l}\text { Het } \\
\text { No mutation }\end{array}$ & $\begin{array}{l}\text { LOH } 10 \mathrm{q} 23 \\
\text { No mutation }\end{array}$ & $\mathrm{LOH}$ & Het \\
\hline $\mathrm{G} 4^{2}$ & Primary & D5S346 & No & 1.9 & n.i. & $\begin{array}{l}\text { LOH 10q23 } \\
\text { No mutation }\end{array}$ & Het & Het \\
\hline G5 & Primary & $\begin{array}{l}\text { D3S1300 } \\
\text { D3S1619 } \\
\text { D13S153 } \\
\text { D17S250 }\end{array}$ & $\begin{array}{l}\text { hMLH1 } \\
\text { hPMS2 }\end{array}$ & 1.3 & $\begin{array}{l}\text { LOH } 17 \mathrm{p} 13 \\
\text { Mut. codon 175, } 199\end{array}$ & $\begin{array}{l}\text { LOH 10q23 } \\
\text { No mutation }\end{array}$ & Het & Het \\
\hline G6 & Primary & D3S1619 & No & 1.6 & $\begin{array}{l}\text { LOH } 17 \mathrm{p} 13 \\
\text { No mutation }\end{array}$ & $\begin{array}{l}\text { Het } \\
\text { No mutation }\end{array}$ & Het & $\mathrm{LOH}$ \\
\hline G7 & Relapse & D5S346 & No & 21.1 & $\begin{array}{l}\text { Het } \\
\text { No mutation }\end{array}$ & $\begin{array}{l}\text { LOH } 10 \mathrm{q} 23 \\
\text { No mutation }\end{array}$ & Het & n.i. \\
\hline $\mathrm{G} 8^{2}$ & Relapse & D5S346 & No & 1.3 & $\begin{array}{l}\text { Het } \\
\text { No mutation }\end{array}$ & $\begin{array}{l}\text { LOH 10q23 } \\
\text { Mut. codon } 105\end{array}$ & $\mathrm{LOH}$ & Het \\
\hline G9 & Relapse & $\begin{array}{l}\text { MYCL1 } \\
\text { D5S346 }\end{array}$ & No & 29.6 & $\begin{array}{l}\text { Het } \\
\text { No mutation }\end{array}$ & $\begin{array}{l}\text { LOH 10q23 } \\
\text { IVS } 8+32 \mathrm{G}>\mathrm{T}\end{array}$ & Het & Het \\
\hline G10 & Relapse & D18S58 & No & 1.4 & $\begin{array}{l}\mathrm{LOH} \\
\text { No mutation }\end{array}$ & $\begin{array}{l}\text { LOH 10q23 } \\
\text { No mutation }\end{array}$ & Het & $\mathrm{LOH}$ \\
\hline G11 & Relapse & D13S153 & No & 14.4 & $\begin{array}{l}\text { Het } \\
\text { No mutation }\end{array}$ & $\begin{array}{l}\text { LOH 10q23 } \\
\text { Mut. codon } 88\end{array}$ & Het & $\mathrm{LOH}$ \\
\hline
\end{tabular}

MSI = Microsatellite instability; $\mathrm{LOH}=$ loss of heterozygosity; 2 = patients with previous lower grade astrocytoma; Het $=$ allelic balance; $n . i .=$ not informative; Mut. = mutation; $E G F R / C F T R$ ratios $>3.91$ were indicative of $E G F R$ amplification. Aberrant MMR protein is referred to the expression of MMR proteins by immunohistochemistry.

ly. In this patient, $\mathrm{LOH}$ at $17 \mathrm{p} 13$ was observed as well. Two further MSI+ GBMs showed LOH at $17 \mathrm{p} 13$ without p53 sequence alterations. In MSS tumors we detected mutations of $p 53$ more frequently $(7 / 26,27 \%)$, including 6 single base pair exchanges on exons 2,4 and 8 , which predicted amino acid substitutions in 5 cases as well as one deletion on exon 7 (nt 13316_13321delAACAGT). Table 2 shows the results of the analyses of CIN pathways in both MSI and MSS GBMs.

Concerning PTEN, mutations in MSI+ GBMs were observed in 2 cases $(2 / 11,18 \%)$ on exon 5 . In MSS glioblastomas, mutations of PTEN were detected in 12 of 26 cases $(46.2 \%)$, consisting in 10 base pair exchanges on exons 2, 5,6 and 7, predicting amino acid substitutions in 8 cases. Two acceptor splice site heterozygous mutations on exon 9 (IVS9-2A>G) were observed as well. The rates of PTEN mutations were higher in both MSS primary and MSS relapses compared with primary and relapse MSI+ tumors ( 38 vs. $14 \%, \mathrm{p}=0.18$ and 54 vs. $25 \%, \mathrm{p}=0.2$, respectively). LOH at 10q23-24 was found in MSI+ and MSS GBMs in 72 and $80.7 \%$, respectively.
The $E G F R / C F T R$ ratios of the $11 \mathrm{MSI}+$ glioblastomas are displayed in table 3 . The cut-off level for a normal gene copy number $(\mathrm{x}+3 \mathrm{SD})$ was 3.91 . Four of $11 \mathrm{MSI}+$ GBMs and 12 out of 26 MSS tumors (36.4 and 46.2\%, respectively) showed ratios $>3.91$, thus indicating amplification of the $E G F R$ oncogene. In recurrences, amplification of $E G F R$ was more frequent in MSI+ tumors than in MSS GBMs ( 60 vs. $38 \%, p=0.25$ ). In contrast, in primary glioblastomas we detected a higher rate of EGFR amplification in MSS tumors than in MSI+ GBMs (53.8 vs. $16.7 \%, \mathrm{p}=0.15$ ).

\section{Discussion}

The MMR genes play an important role in maintaining the genetic stability of DNA. Inactivation of these genes may lead to a mutator phenotype, which has been proposed to promote accumulation of alterations in oncogenes and tumor suppressor genes [12,13]. This mutator phenotype has been observed in HNPCC-associated MSI$\mathrm{H}$ malignancies as well as in sporadic tumors harboring 
distinct molecular features [26, 27]. Furthermore, sporadic colon cancers showing low-level MSI were found to display higher rates of $K-R A S$ mutations, $M G M T$ promoter hypermethylation and a different genome-wide LOH profile than MSS colon carcinomas [41, 42].

A comprehensive study of MSI in the pathogenesis of GBM including the investigation of the molecular alterations associated with MSI, the involvement of the MMR system as well as the relationship with the CIN-dependent events, has not been performed. Some reports analyzed MSI in glioblastomas either investigating small GBM series [43-46] or using few microsatellite markers [47]. Contributing to this heterogeneous situation, different instability criteria and methods were used. We investigated MSI in 129 GBM patients (109 newly diagnosed, 20 relapses) with 15 polymorphic repeats as recommended by the National Cancer Institute [27] and observed MSI-L in 11 of $129(8.5 \%)$ GBMs. Similarly to other sporadic MSI+ non-HNPCC non-colonic cancers such as gastric or endometrial carcinomas, the most sensitive markers were dinucleotides, larger repeats such as the tetranucleotide MYCL1 being only occasionally mutated.

Evaluating the clinicopathological tumor features by MSI status, we found that the incidence of MSI was more elevated in patients previously treated for an astrocytoma WHO grade II or III than in clinically de novo glioblastomas $(12.5$ vs. $6.5 \%, \mathrm{p}=0.18)$. This indicates a trend between MSI and progression of lower grade astrocytomas to GBM. Similarly, instability was observed to be more frequent in advanced than in early gastric cancers. Furthermore, MSI was evidenced in metastatic gastric cancers, but was absent in neighboring metaplastic epithelium [26].

An aberrant MMR protein expression was found only in one MSI+ tumor, a giant-cell GBM. This subtype is a peculiar variant of ordinary GBM, making about $5 \%$ of the total [3, 48]. Interestingly, only the giant cell type showed these staining alterations, whereas the non-giant cell type harbored a positive staining. An inactivation of hMLH1 through mutation or promoter hypermethylation could not be found. Taking into account the histological characteristics of giant cell GBM, the possibility that $h M L H 1$ mutations or hypermethylation of the $h M L H 1$ promoter only affected the giant cell phenotype cannot be excluded. Alternatively, a transcriptional silencing concerning only the giant cells might also lead to this condition. The positive expression of MMR proteins in most of MSI+ tumors remarked the similarities between the MSI+ GBMs and the MSI+ gastric or endometrial carcinomas regarding instability pattern $[49,50]$. This suggests that in most GBMs MSI might rather be explained by inactivation of minor MMR genes (for instance, hMSH3 or hPMS1), mutations leading to a dominant negative phenotype as reported for $h P M S 2$ [51] or an imbalance in the relative amount of MMR proteins as shown for hMSH3 and hMSH6 [52].

Glioblastoma cells may evade growth control mechanisms through CIN-dependent genetic changes such as aneuploidy, chromosome rearrangements and accumulation of somatic genetic mutations [53, 54]. Two CIN pathways were described in the pathogenesis of about $70 \%$ of GBMs, defining type 1 and type 2 GBM [5-7]. In the present analysis, $55 \%$ of the MSI+ tumors displayed a non-type 1, non-type 2 profile, whereas in the MSS control group such patterns were found in $27 \%$ of the cases. Nevertheless, since MSI was not observed in all non-type 1, non-type 2 GBM, further molecular alterations should be responsible for this GBM group. A negative association between mutations of $p 53$ and MSI was observed and $p 53$ mutations were detected only in one MSI+ giant cell GBM, which typically shows a higher rate of $p 53$ mutations $[48,55]$. Additionally, only missense $p 53$ mutations were detected but not insertions/deletions at iterated bases, thus making the possibility that MSI caused p53 alterations unlikely. Similar results emerged from the analysis of MSI+ gastric carcinomas [19]. PTEN mutations in both primary and relapse GBMs were also found to be inversely associated with MSI. On the other hand, it was observed in GBM patients with Turcot syndrome and germline mutations of MMR genes that both $p 53$ inactivation and chromosomal instability were present in the glioblastomas, but not in the metachronous colorectal carcinomas also developing in these patients [56]. Furthermore, none of the PTEN mutations in MSI+ tumors were observed in the polyadenine repeat of exon 8 , a frequent target in MSI+ cancers. This finding distinguished the MSI pattern of GBMs from other MSI+ cancers, such as endometrial carcinomas, usually showing this type of $P T E N$ mutation [15, 57]. Amplification of EGFR was more frequent in MSI+ relapses than in MSS recurrences. To our knowledge, such relationship has not been reported before.

Less is known about the timing of microsatellite instability in tumorigenesis. In the present study we detected a significantly higher MSI rate in relapses compared to primary tumors ( 25 vs. $5.5 \%, p=0.027)$. Since all patients underwent radiotherapy after the first surgical procedure, a possible explanation is a radiation-induced damage in the mechanisms of DNA repair. However, by sequencing p53 and PTEN we did not find alterations such as base 
pair deletions suggesting ionizing radiation-induced DNA damage. This is in accordance with previous observations in solid tumors developed after radiotherapy, in which high chromosomal instability but no MSI could be observed [58].

The present analysis provides evidence that MSI and chromosomal instability in glioblastoma most likely follow independent pathways, as indicated by the inverse association between MSI and mutations of $p 53$ and PTEN as well as the observed mutation types in these genes. The higher incidence of MSI in relapse GBMs might be compatible with a mutator phenotype that could predispose to the development of recurrences.

\section{Acknowledgments}

This study was supported by the Deutsche Forschungsgemeinschaft (grant No. MA 2448/1/1). We thank C. Voelter, MD, ENT Department, University of Würzburg, for helpful discussions, L. Moser, PhD, ENT Department, University of Würzburg, Germany and B. Wiedemann, PhD, Institute of Biometry, University of Dresden, Germany, for helpful assessment of statistical analyses. We also thank A. Serra, MD, PhD for helpful advice on the immunohistochemical densitometry studies and Mrs. M. Reichmann for her skillful technical assistance. The authors are indebted to S. Scherneck, MD, the Department of Surgery and Surgical Oncology, Robert-Roessle Clinic, Berlin, Germany, for kindly providing the breast cancer cell line CAL51.

\section{References}

1 Lengauer C, Kinzler KW, Vogelstein B: Genetic instabilities in human cancers. Nature 1998; 396:643-649.

2 Kinzler KW, Vogelstein B: Cancer susceptibility genes. Gatekeepers and caretakers. Nature 1997;386:761-763.

3 Kleihues P, Louis DN, Scheithauer BW, Rorke LB, Reifenberger G, Burger PC, Cavenee WK: The WHO classification of tumors of the nervous system. J Neuropathol Exp Neurol 2002; 61:215-225.

4 Lacroix M, Abi-Said D, Fourney DR, Gokaslan ZL, Shi W, DeMonte F, Lang FF, McCutcheon IE, Hassenbusch SJ, Holland E, Hess K, Michael C, Miller D, Sawaya R: A multivariate analysis of 416 patients with glioblastoma multiforme: Prognosis, extent of resection and survival. J Neurosurg 2001;95:190-198.

5 Von Deimling A, von Ammon K, Schoenfeld D, Wiestler OD, Seizinger BR, Louis DN: Subsets of glioblastoma multiforme defined by molecular genetic analysis. Brain Pathol 1993;3: 19-26.

6 Von Deimling A, Louis DN, Wiestler OD: Molecular pathways in the formation of gliomas. Glia 1995; 15:328-338.

7 Reifenberger G, Liu L, Ichimura K, Schmidt KK, Collins VP: Amplification and overexpression of the MDM2 gene in a subset of human malignant gliomas without p53 mutations. Cancer Res 1993;53:2736-2739.

8 Lang F, Miller D, Koslow M, Newcomb E: Pathways leading to glioblastoma multiforme: A molecular analysis of genetic alterations in 65 astrocytic tumors. J Neurosurg 1994;81: 427-436.

9 Hayashi Y, Ueki K, Waha A, Wiestler OD, Louis DN, von Deimling A: Association of gene amplification and CDKN2A (p16/MTS1) gene deletion in glioblastoma multiforme. Brain Pathol 1997;7:871-875.

10 Louis DN: A molecular genetic model of astrocytoma histopathology. Brain Pathol 1997;7: 755-764.

11 Collins VP: Gliomas. Cancer Surv 1998;32:37_ 51.
12 Thibodeau SN, Bren G, Schaid D: Microsatellite instability in cancer of the proximal colon. Science 1993;260:816-819.

13 Ionov Y, Peinado A, Malkhosyan D, Shibata D, Perucho M: Ubiquitous somatic mutations in simple repeated sequences reveal a new mechanism for colonic carcinogenesis. Nature 1993;363:558-561.

14 Rampino N, Yamamoto H, Ionov Y, Li Y, Sawai H, Reed JC, Perucho M: Somatic frameshift mutations in the BAX gene in colon cancers of the microsatellite mutator phenotype. Science 1997;275:967-969.

15 Kong D, Suzuki A, Zou TT, Sakurada A, Kemp LW, Wakatsuki S, Yokoyama T, Yamakawa H, Furukawa T, Sato M, Ohuchi N, Sato S, Yin J, Wang S, Abraham JM, Souza RF, Smolinski KN, Meltzer SJ, Horii A: PTEN1 is frequently mutated in primary endometrial carcinomas. Nat Genet 1997;17:143-144.

16 Aaltonen LA, Peltomäki P, Leach FS, Sistonen P, Pylkkänen L, Mecklin JP, Järvinen H, Powell SM, Hamilton SR: Clues to the pathogenesis of familial colorectal cancer. Science 1993;260: 812-816.

17 Lothe RA, Peltomaki P, Meling GI, Aaltonen LA, Nystrom-Lahti M, Pylkkanen L, Heimdal K, Andersen TI, Moller P, Rognum TO: Genomic instability in colorectal cancer: Relationship to clinicopathological variables and family history. Cancer Res. 1993;53:58495852.

18 Caduff RF, Johnston CM, Svoboda-Newman SM, Poy EL, Merajver SD, Frank TS: Clinical and pathological significance of microsatellite instability in sporadic endometrial carcinoma. Am J Pathol 1996;148:1671-1678.

19 Renault B, Calistri D, Buonsanti G, Nanni O, Amadosi D, Ranzani GN: Microsatellite instability and mutations of $\mathrm{p} 53$ and TGF- $\beta$ RII genes in gastric cancers: Hum Genet 1996;98: 601-607.

20 Field JK, Kiaris H, Howard P, Vaughan ED, Spandidos DA, Jones AS: Microsatellite instability in squamous cell carcinoma of the head and neck. Br J Cancer 1995; 71:1065-1069.
21 Wooster R, Cleton-Jansen AM, Collins VP, Mangion J, Cornelis RS, Cooper CS, von Deimling A, Wiestler OD, Stratton MR: Instability of short tandem repeats (microsatellites) in human cancer. Nat Genet 1994;6:152-156.

22 Watanabe $M$, Imai $H$, Kato $H$, Shiraishi $T$, Ushijima T, Nagao M, Yatani R: Microsatellite instability in latent prostate cancers. Int J Cancer 1996;69:394-397.

23 Kane MF, Loda M, Gaida G, Lipman J, Mishra R, Goldman H, Jessup JM, Kolodner R: Methylation of the hMLH1 promoter correlates with lack of expression of hMLH1 in sporadic colon tumors and mismatch repair-defective human tumor cell lines. Cancer Res 1997; 57:808-811.

24 Cottu PH, Muzeau F, Estreicher A, Flejou JF, Iggo R, Thomas G, Hamelin R: Inverse correlation between RER + status and p53 mutation in colorectal cancer cell lines. Oncogene 1996;13: 2727-2730.

25 Kim JJ, Baek MJ, Kim L, Kim NG, Lee YC, Song SY, Noh SH, Kim H: Accumulated frameshift mutations at coding nucleotide repeats during the progression of gastric carcinoma with microsatellite instability. Lab Invest 1999; 79:1113-1120.

26 Strickler JG, Zheng J, Shu Q, Burgart LJ, Alberts SR, Shibata D: p53 mutations and microsatellite instability in sporadic gastric cancer: when guardians fail. Cancer Res 1994;54: 4750-4755.

27 Boland R, Thibodeau S, Hamilton S, Sidransky D, Eshleman J, Rodriguez-Bigas MA, Fodde R, Ranzani GN, Srivastava SA: National Cancer Institute workshop on microsatellite instability for cancer detection and familial predisposition: Development of international criteria for the determination for microsatellite instability in colorectal cancer. Cancer Res 1998;58: 5248-5257.

28 Dietmaier W, Wallinger S, Bocker T, Kullman F, Fishel R, Ruschoff J: Diagnostic microsatellite instability: Definition and correlation with mismatch repair protein expression. Cancer Res 1997;57:4749-4756. 
29 Plaschke J, Kruppa C, Tischler R, Bocker T, Pistorius S, Dralle H, Rüschoff J, Saeger HD, Fishel R, Schackert HK: Sequence analysis of the mismatch repair gene hMSH6 in the germline of patients with familial and sporadic colorectal cancer. Int J Cancer 2000;85:606-613.

30 Oda S, Oki E, Maehara Y, Sugimachi K: Precise assessment of microsatellite instability using high resolution fluorescent microsatellite analysis. Nucleic Acids Res 1997;25:34153420 .

31 Cawkwell L, Lewis FA, Quirke P: Frequency of allele loss of DCC, p53, RB1, WT1, NF1, NM23 and APC/MCC in colorectal cancer assayed by fluorescent multiplex polymerase chain reaction. Br J Cancer 1994;70:813-818.

32 Hahn M, Wieland I, Koufaki ON, Görgens H, Sobottka SB, Schackert G, Schackert HK: Genetic alterations of the tumor suppressor gene PTEN/MMAC1 in human brain metastases. Clin Cancer Res 1999;5:2431-2437.

33 Thibodeau SN, French AJ, Cunningham JM, Teter D, Burgart LJ, Roche PC, McDonnell SK, Schaid DJ, Vockley CW, Michels VV, Farr GH Jr., Connell MJ: Microsatellite instability in colorectal cancers: different mutator phenotypes and the principal involvement of hMLH1. Cancer Res 1998;58:1713-1718.

34 Plaschke J, Kruger S, Pistorius S, Theissig F, Saeger HD, Schackert HK: Involvement of hMSH6 in the development of hereditary and sporadic colorectal cancer revealed by immunostaining is based on germline mutations, but rarely on somatic inactivation. Int $\mathrm{J}$ Cancer 2002;97:643-648

35 Kolodner RD, Hall NR, Lipford J, Kane MF, Morrison PT, Finan PJ, Burn J, Chapman P, Earabino C, Merchant E: Structure of the human MLH1 locus and analysis of a large hereditary nonpolyposis colorectal carcinoma kindred for mlh1 mutations. Cancer Res 1995 . 55:242-248.

36 Steck PA, Pershouse MA, Jasser SA, Yung WK, Lin H, Ligon AH, Langford LA, Baumgard ML, Hattier T, Davis T, Frye C, Hu R, Swedlund B, Teng DH, Tavtigian SV: Identification of a candidate tumor suppressor gene, MMAC1, at chromosome 10q23.3 that is mutated in multiple advanced cancers. Nat Genet 1997; 15:356-362.

37 Liaw D, Marsh DJ, Li J, Dahia PL, Wang SI, Zheng Z, Bose S, Call KM, Tsou HC, Peacocke M, Eng C, Parsons R: Germline mutations of the PTEN gene in Cowden disease, an inherited breast and thyroid cancer syndrome. Nat Genet 1997;16:64-67.
38 Seitz S, Wassmuth P, Plaschke J, Schackert HK, Karsten U, Santibanez-Koref MF, Pankow H, Schlag PM, Scherneck S: Identification of microsatellite instability and mismatch repair gene mutations in breast cancer cell lines. Genes Chromosomes Cancer 2003;37:29-35.

39 Kraus JA, Lamszus K, Glesmann N, Beck M, Wolter M, Sabel M, Krex D, Klockgether T, Reifenberger G, Schlegel: Molecular genetic alterations in glioblastomas with oligodendroglial component. Acta Neuropathol (Berl) 2001;101:311-320.

40 Hunter SB, Abbott K, Varma VA, Olson JJ, Barnett DW, James D: Reliability of differential PCR for the detection of EGFR and MDM2 gene amplification in DNA extracted from FFPE glioma tissue. J Neuropathol Exp Neurol 1995;54:57-64.

41 Whitehall VL, Walsh MD, Young J, Leggett A, Jass JR: Methylation of O-6-methylguanine DNA methyltransferase characterizes a subset of colorectal cancer with low-level DNA microsatellite instability. Cancer Res 2001;61:827830.

42 Kambara T, Matsubara N, Nakagawa H, Notohara K, Nagasaka T, Yoshino T, Hisozaki $\mathrm{H}$, Sharp G, Shimizu K, Jass J, Tanaka N: High frequency of low-level microsatellite instability in early colorectal cancer. Cancer Res 2001;61: 7743-7746.

43 Dams E, van der Kelft EJ, Martin JJ, Verlooy J, Willems PJ: Instability of microsatellites in human gliomas. Cancer Res 1995;55:1547-1549.

44 Zhu JJ, Guo SZ, Beggs AH, Muruyama, T, Santarius T, Dashner K, Olsen N, Wu J, Black PM: Microsatellite instability analysis of primary human brain tumors. Oncogene 1996;12: 1417-1423.

45 Izumoto S, Arita N, Ohnishi T, Hiraga S, Taki T, Tomita N, Ohue M, Hayakawa T: Microsatellite instability and mutated transforming growth factor- $\beta$ receptor gene in gliomas. Cancer Lett 1997;112:251-256.

46 Sobrido MJ, Rodriguez P, Barros F, Forteza J, Carracedo A, Lema M: Low frequency of replication errors in primary nervous system tumors. J Neurol Neurosurg Psychiatry 2000;69: 369-375.

47 Alonso M, Hamelin R, Kim M, Porwancher K, Sung T, Parhar P, Miler DC, Newcomb EW: Microsatellite instability occurs in distinct subtypes of pediatric but not adult central nervous system tumors. Cancer Res 2001;61:21242128.

48 Peraud A, Watanabe K, Schwechheimer K, Yonekawa Y, Kleihues P, Ohgaki H: Genetic profile of the giant cell glioblastoma. Lab Invest 1999;79:123-129.
49 Wu MS, Sheu JC, Shun CT, Lee WJ, Wang JT, Wang TH, Cheng AL, Lin JT: Infrequent hMSH2 mutations in sporadic gastric adenocarcinoma with microsatellite instability. Cancer Lett 1997;112:161-166.

50 Katabuchi H, van Rees B, Lambers AR, Ronnett BM, Blazes MS, Leach FS, Cho KR, Hedrick L: Mutations in DNA mismatch repair genes are not responsible for microsatellite instability in most sporadic endometrial carcinomas. Cancer Res 1995;55:5556-5560.

51 Nicolaides NC, Littman SJ, Modrich P, Kinzler KW, Vogelstein B: A naturally occurring hPMS2 mutation can confer a dominant negative mutator phenotype. Mol Cell Biol 1998; 18 : 1635-1641.

52 Marra G, Iaccarino I, Lettieri T, Roscilli G, Delmastro P, Jiricny J: Mismatch repair deficiency associated with overexpression of the MSH3 gene. Proc Natl Acad Sci USA 1998;95: 8568-8573.

53 Hui AB, Lo KW, Yin XL, Poon WS, Ng HK: Detection of multiple gene amplifications in glioblastoma multiforme using array-based comparative genomic hybridization. Lab Invest 2001;81:717-723.

54 Mao X, Hamoudi RA: Molecular and cytogenetic analysis of glioblastoma multiforme. Cancer Genet Cytogenet 2000;122:87-92.

55 Meyer-Puttlitz B, Hayashi Y, Waha A, Rollbrocker B, Boström J, Wiestler O, Louis DN, Reifenberger $G$, von Deimling A: Molecular genetic analysis of giant cell glioblastomas. Am J Pathol 1997;151:853-857.

56 Leung SY, Yuen ST, Chan TL, Chan ASY, Ho JWC, Kwan K, Fan YW, Hung KN, Chung LP, Wyllie AH: Chromosomal instability and p53 inactivation are required for genesis of glioblastoma but not for colorectal cancer in patients with germline mismatch repair gene mutation. Oncogene 2000;19:4079-4083.

57 Bussaglia E, del Rio E, Matias-Guiu X, Prat J: PTEN mutations in endometrial carcinomas: A molecular and clinicopathologic analysis of 38 cases. Hum Pathol 2000;31:312-317.

58 Lefevre SH, Vogt N, Dutrillaux AM, Chauveinc L, Stoppa-Lyonnet D, Doz F, Desjardins L, Dutrillaux B, Chevillard S, Malfoy B: Genome instability in secondary solid tumors developing after radiotherapy of bilateral retinoblastoma. Oncogene 2001;20:8092-8099. 